\title{
A REEXAMINATION OF EARTHQUAKES PREVIOUSLY THOUGHT TO HAVE OCCURRED WITHIN THE SLAB BETWEEN THE TRENCH AXIS AND DOUBLE SEISMIC ZONE, NORTHERN HONSHU ARC
}

\author{
Tetsuzo SENo* and Glenn C. KROEGER \\ Department of Geophysics, Stanford University, Stanford, CA 94305, U.S.A. \\ (Received June 21, 1983; Revised November 18, 1983)
}

\begin{abstract}
We have studied earthquakes along the northern Honshu arc, Japan, which were previously thought to have occurred within the downgoing slab, landward of the trench axis and seaward of the double seismic zone. We used P-wave synthetic seismograms to determine precise source depths and mechanisms. We examined six earthquakes in the zone from $50 \mathrm{~km}$ to $150 \mathrm{~km}$ landward of the trench axis whose published focal mechanisms showed normal faulting or $\mathrm{T}$ axes subparallel to the dip of the slab. These events were thought to have occurred within the slab due to their focal mechanisms. When we computed body-wave synthetics, however, five of these six events were shown to be of thrust type and located at the plate interface. Our synthetics confirm that the sixth event (March 16, 1969, $m_{\mathrm{b}}=5.5, M_{\mathrm{s}}=5.5$ ), located about $100 \mathrm{~km}$ landward of the trench axis, definitely occurred within the slab $15 \mathrm{~km}$ below the plate interface. We obtain a focal mechanism with $\mathrm{T}$ axis dipping at an angle of $60^{\circ}$. The location of this event is about $50 \mathrm{~km}$ seaward from the edge of the double seismic zone. The bending-unbending theory of an elastic-plastic plate cannot explain the stress axis of this event; however, the gravitational pull or sagging of the downgoing slab is consistent with this stress orientation.
\end{abstract}

\section{Introduction}

Seismicity in subduction zones can be separated into three groups: activity within the overriding plate, activity at the plate interface, and activity within the downgoing oceanic plate. The activity within the oceanic plate is well known in the Wadati-Benioff zone at intermediate and greater depths. It is also known in the region seaward of and beneath the trench axis. However, the activity within the slab between these two regions is less known and has not yet been well studied. We have concentrated our efforts on this activity in this study. We studied those earthquakes which might have occurred in the shallower portion of the descending slab landward of the trench and seaward of the double seismic zone in the northern Honshu arc. We determined precise focal mechanisms and depths by

* Present address: International Institute of Seismology and Earthquake Engineering, Building Research Institute, Ministry of Construction, Tsukuba, Ibaraki, Japan. 


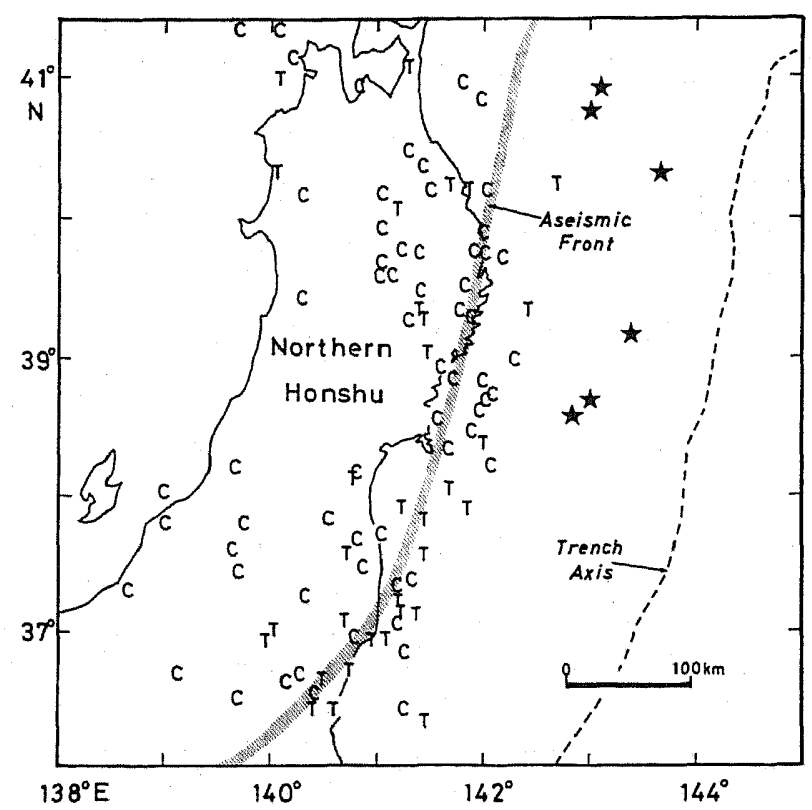

Fig. 1. Map distribution of down-dip compression, denoted by $\mathrm{C}$, and down-dip tension, denoted by $\mathrm{T}$, type events in northern Honshu (data from KaWAKaTsU and SENO, 1983). The location of the aseismic front is from YoshiI (1979b). Those events studied are indicated by asterisks.

calculating synthetics of long-period P-waves and comparing them with observed seismograms.

The northern Honshu arc is the best place to study this activity because the seaward edge of the double seismic zone is well defined there. Figure 1 shows the distribution of down-dip compression and down-dip tension type events in the northern Honshu arc (Kawakatsu and Seno, 1983; Seno and Pongsawat, 1981). These events are located as far as $50 \mathrm{~km}$ seaward of the aseismic front. The epicentral location of the events studied are indicated by stars in this figure; they are located farther seaward than the down-dip compression or down-dip tension type events. Because a number of thrust type events occur in the northern Honshu arc, we can use them to define the plate interface and locate possible intraplate events with respect to the interface.

Previous seismological studies in some island arcs suggest that there is activity in the shallow portion of the slab landward of the trench. ABE (1972) and STAUDER (1975) obtained normal fault solutions for events in the depth range of 50-62 km near the coast of Peru. Malgrange et al. (1981), Malgrange and MADARIAGA (1983), and STAUDER (1973) also showed that large normal fault type earthquakes occurred off the Chilean coast in the shallow (40-72 km) depth range. Although their precise location with respect to the downgoing plate is not known, their mechanism solutions indicate that these events are likely to 
have occurred within the descending slab at the shallow portion landward of the trench axis as ABE (1972) and MALGRANGE et al. (1981) suggested.

In the Lesser Antilles and New Hebrides, STEIN et al. (1982) and Chung and KANAMORI (1978), respectively, obtained strike-slip type mechanisms for earthquakes located landward of the trench axis in the depth range of $41-56 \mathrm{~km}$. These events are difficult to interpret in terms of the relative plate motions; they could be interpreted as deformation within the plate, although the relative location of these events to the plate interface was not determined in these studies. In the Aleutians, HousE and JACOB (1983) obtained strike-slip, normal fault, and reverse fault type mechanisms landward of the trench axis in the depth range of $30-45 \mathrm{~km}$ which are also difficult to interpret in terms of the differential plate motion along this arc. In the eastern part of this arc, REYNERs and Coles (1982) found some events which occurred around $25 \mathrm{~km}$ deep probably within the descending plate landward of the trench axis by identifying $S / P$ and $P / S$ conversion phases at the plate interface recorded at local microseismic stations. Similarly, SHIMAMURA (1973) noted several events which might have occurred within the descending slab in the southern Kurile arc at the depth range of $20-50 \mathrm{~km}$ by identifying $\mathrm{S} / \mathrm{P}$ conversion phases at the plate interface.

In the northern Honshu arc, there are previous studies suggesting the possible occurrence of earthquakes within the shallow portion of the slab landward of the trench. SASATANI (1971) analyzed P-wave first motions recorded in the Japanese islands and classified events into normal fault type and reverse fault type from the distribution of the first motions along the islands. He noted that normal fault type events are dominant east of latitude $143^{\circ} \mathrm{E}$ off the coast of northern Honshu and west of the trench axis. ABE (1977) analyzed a series of five large earthquakes which occurred in 1938 off the southern coast of northern Honshu and obtained two normal fault type events in the depth range of $20-40 \mathrm{~km}$. YOSHII (1979a) described a characteristic pattern of faulting in the northern Honshu arc based on the mechanism solutions which had been obtained, and stated that normal fault type events occur predominantly within the shallow portion of the descending slab landward of the trench axis.

Although there are a number of studies suggesting the possible occurrence of earthquakes within the relatively shallow portion of the slab landward of the trench axis, precise locations of those events with respect to the plate interface or the slab have not been determined. Although previous studies using the body-wave conversions may provide the most accurate location of the events with respect to the plate interface, identification of the phases is often not unique, and fault type is unknown in these studies.

In this study we have determined precise source depth of events which might have occurred within the downgoing plate beneath northern Honshu with respect to the plate interface. A schematic illustration of subduction seismicity along the northern Honshu arc is shown in Fig. 2 in a cross-section perpendicular to the trench axis. Precise source depth of intraplate events with respect to the plate 


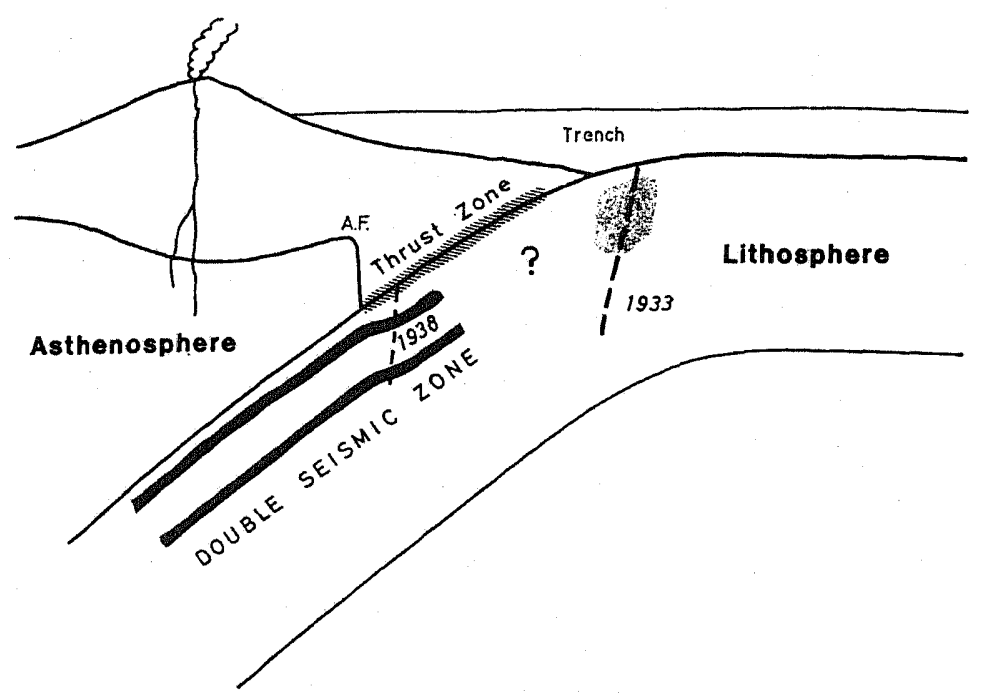

Fig. 2. Schematic illustration of subduction seismicity along the northern Honshu arc in a cross-section perpendicular to the trench axis. Zones of seismicity are shaded. Faulting caused by the 1933 and 1938 normal fault type earthquakes (KANAMORI, 1971a; ABE, 1977) is indicated by the broken lines. The area of ? is studied in this paper.

interface and their focal mechanism will provide important information on the stress state within the oceanic plate after it descends from the trench. Below about $60 \mathrm{~km}$ depth, intraplate events constituting the so-called double seismic zone start to occur. Our purpose here was to obtain information on stresses within the shallow portion of the slab where stresses creating the double seismic zone do not prevail. For example, the bending-unbending model of the oceanic plate does not predict seismicity in this region, and thus we will be able to obtain information on other stresses operating in this portion of the slab.

\section{Events}

We searched for events which might have occurred within the slab between the trench axis and the double seismic zone in the northern Honshu arc during the period 1964-1978 June from File ME 1 of YoseII (1979b), SENo and Pongsawat (1981), Seno (1982) and KawaKatsu and Seno (1983). File ME 1 includes almost all the published mechanisms of earthquakes around Japan during 1964-1975. We selected events which have normal fault type mechanism or $\mathrm{T}$ axis sub-parallel to the dip of the slab and have body-wave magnitudes greater than 5.3. We selected those events because the previous studies (SASATANI, 1971; YosHII, 1979a) suggest that normal faulting is the dominant mode of deformation within the slab in this region. We also needed to select events large enough to allow synthetic modeling of the long-period body-wave seismograms. We 
Earthquakes between the Trench Axis and Double Seismic Zone

Table 1. Earthquakes analyzed.

\begin{tabular}{|c|c|c|c|c|c|c|}
\hline \multirow{2}{*}{ Event } & \multirow{2}{*}{ Date } & \multicolumn{2}{|c|}{ Location } & \multirow{2}{*}{$m_{\mathrm{b}}$} & \multirow{2}{*}{$\begin{array}{l}\text { Depth } \\
(\mathrm{km})\end{array}$} & \multirow{2}{*}{ References } \\
\hline & & $\left({ }^{\circ} \mathrm{N}\right)$ & $\left({ }^{\circ} \mathrm{E}\right)$ & & & \\
\hline I1 & 19650316 & 40.75 & 142.96 & 5.8 & 29 & ICHIKAWA (1971) \\
\hline $\mathrm{I} 2$ & 19680524 & 40.91 & 143.11 & 5.7 & 23 & ICHIKAWA (1971) \\
\hline $\mathrm{Y}$ & 19680622 & 40.31 & 143.68 & 5.6 & 19 & YoshII (1979a) \\
\hline SM & 19710915 & 39.17 & 143.39 & 5.8 & 20 & STAUDER and MUALCHIN (1976 \\
\hline SP1 & 19680421 & 38.68 & 142.99 & 5.4 & 41 & Seno and Pongsawat (1981) \\
\hline SP2 & 19690316 & 38.57 & 142.83 & 5.5 & 37 & SENo and PongsaWAT (1981) \\
\hline
\end{tabular}

Epicentral locations are from the ISC Bulletins. Depth is pP-P ISC depth corrected for water depth.

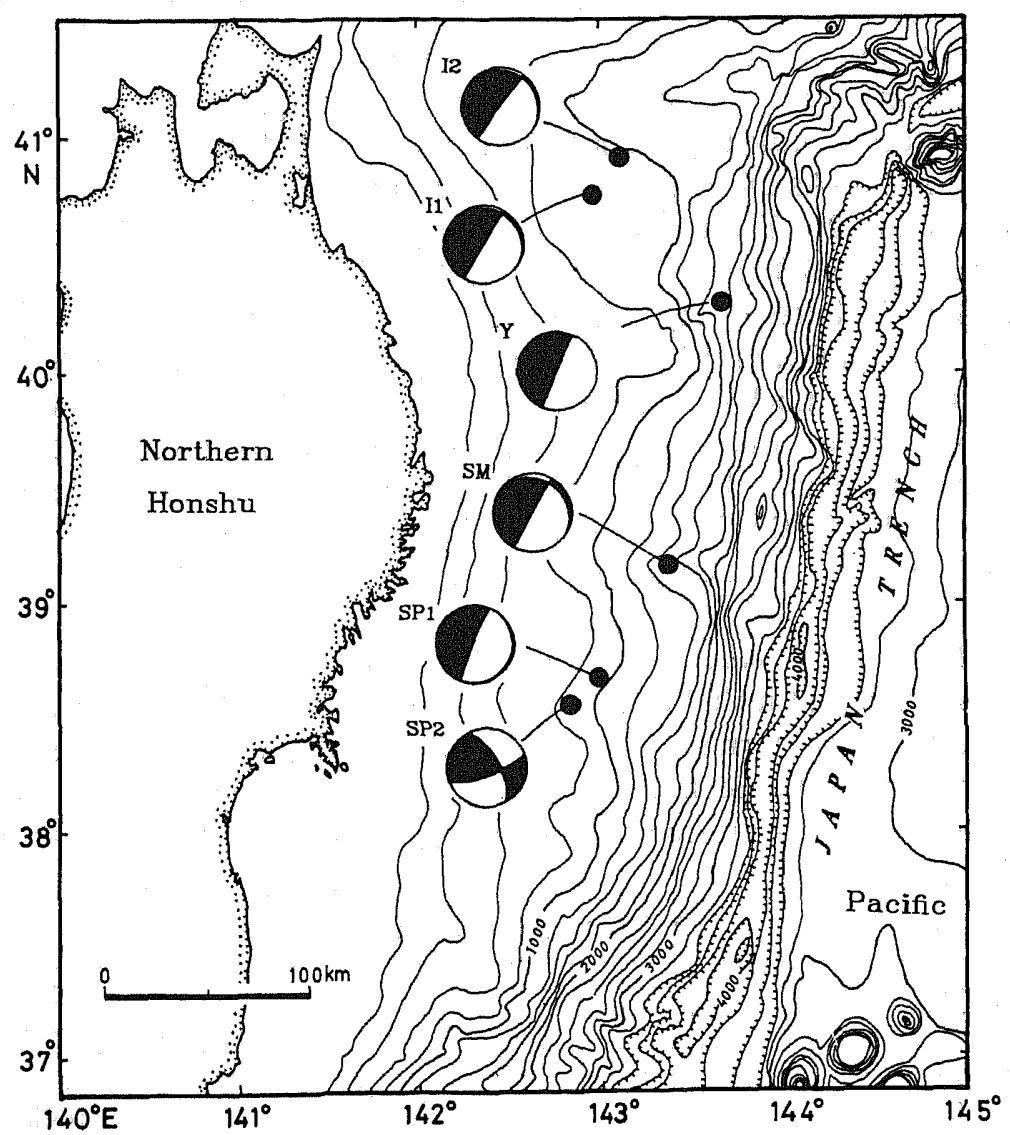

Fig. 3. Epicentral locations and focal mechanisms by the previous authors of the six studied events. Focal mechanism diagrams are equal area projections of the lower hemisphere. Bathymetry of offshore region is after CHASE and MENARD (1969); contour is interval 200 fathom. 
found six events which satisfy these conditions; they are listed in Table 1 and their fault plane solutions from the previous studies and their epicentral locations are shown in the bathymetric map of northern Honshu (Fig. 3, CHASE and MENARD, 1969). These events are denoted by the initials of the authors of their mechanism solutions (Table 1 and Fig. 3). Four of these events (I1, I2, SM, and SP1) have normal fault type mechanisms, and one $(\mathrm{Y})$ has a vertical fault plane and the other (SP2) has a strike-slip fault type mechanism. The horizontal projection of their $\mathrm{T}$ axes are directed perpendicular to the trench axis.

\section{Body-Wave Synthetics}

The method of computation of P-wave synthesized seismograms is described by Kroeger and Geller (1983). This method is based on the first motion approximation of generalized rays (HELMBERGER, 1974; LANGSTON and HELMBERGER, 1975; KANAMORI and STEWART, 1976) and incorporates all significant reflections and conversions from the structure assumed near the source. We used the crustal structure revealed by seismic refraction studies off the Pacific coast of northern Honshu (AsANo et al., 1981) to compute the synthetics. This structure is shown in Table 2. The structure is composed of water layer, sedimentary layer, upper crust $\left(V_{\mathrm{P}}=5.8 \mathrm{~km} / \mathrm{sec}\right)$, lower crust $\left(V_{\mathrm{P}}=6.8 \mathrm{~km} / \mathrm{sec}\right)$ and uppermost mantle. The thickness of the sedimentary layer is varied from $1.0 \mathrm{~km}$ to $2.0 \mathrm{~km}$ to match the synthetics with the observed seismograms. According to this variation, the total thickness of the crust is also varied. The source is assumed to be a point source, which is convolved with instrumental response, trapezoidal source time function and $\mathrm{Q}$ operator $T_{\mathrm{P}}{ }^{*}$ for attenuation. The value of $T_{\mathrm{P}}{ }^{*}$ is assumed as 1.0. In the following subsections, we will describe some details of matching body-wave synthetics with observed seismograms.

\subsection{Effect of the sedimentary layer}

It was found that including the sedimentary layer is essential to match details of the observed waveforms with the synthetics. This is because the reflection from the bottom of the sediment is as large as the reflection from the surface of the earth or from the sea surface. Figure 4 shows an example of calculated pulses

Table 2. Crustal structure.

\begin{tabular}{cccc}
\hline $\begin{array}{c}V_{\mathrm{P}} \\
(\mathrm{km} / \mathrm{sec})\end{array}$ & $\begin{array}{c}V_{\mathrm{s}} \\
(\mathrm{km} / \mathrm{sec})\end{array}$ & $\begin{array}{c}\rho \\
\left(\mathrm{g} / \mathrm{cm}^{3}\right)\end{array}$ & $\begin{array}{c}\text { Thickness } \\
(\mathrm{km})\end{array}$ \\
\hline 1.52 & 0.0 & 1.0 & $1.5 \sim 2.7$ \\
2.0 & 1.15 & 2.0 & $1.0 \sim 2.0$ \\
5.8 & 3.35 & 2.5 & 15.6 \\
6.8 & 3.93 & 2.8 & 6.0 \\
8.14 & 4.68 & 3.3 & $\infty$ \\
\hline
\end{tabular}

After Asano et al. (1981). 


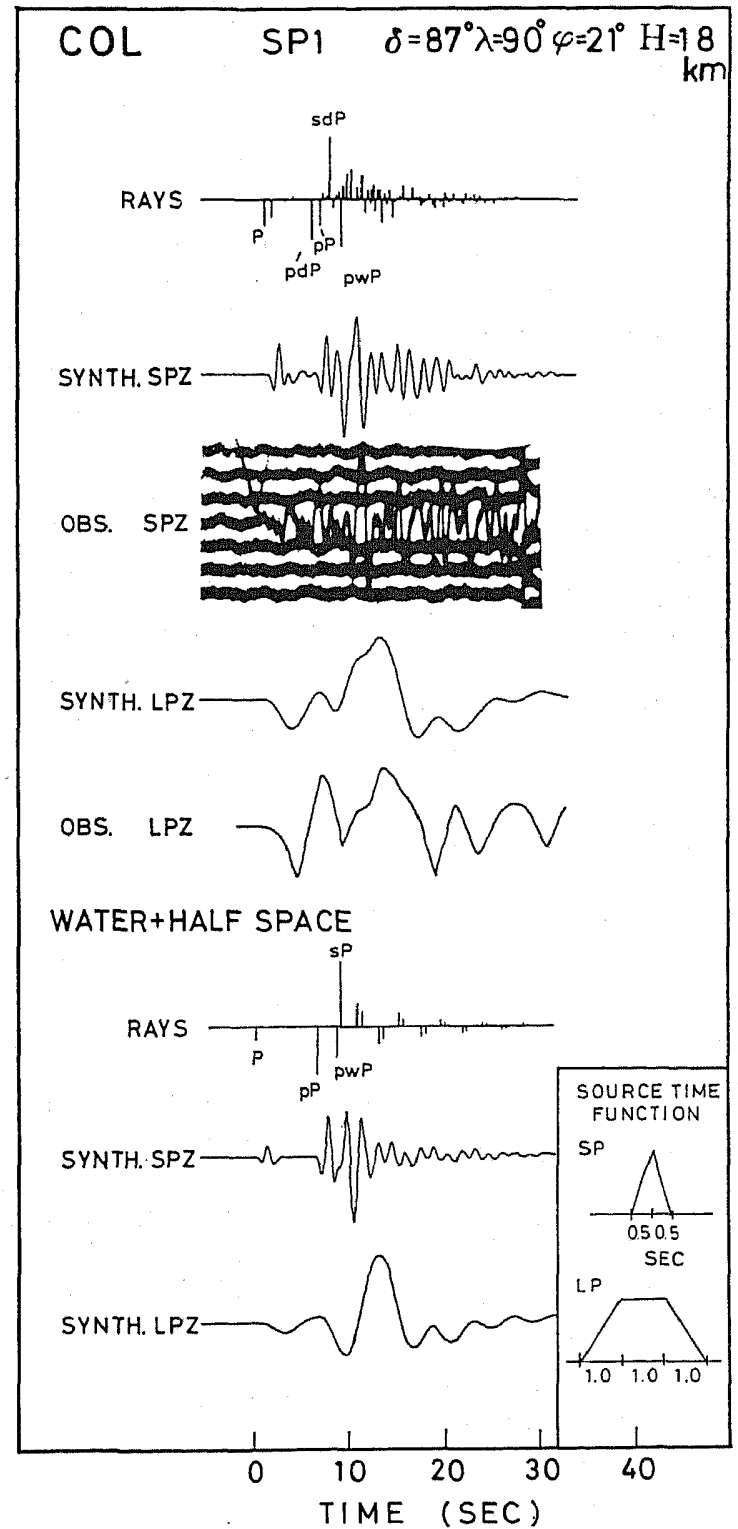

Fig. 4. Synthesized and observed short and long-period seismograms at COL station for SP1 event. Pulses of rays and synthetics are shown for two modelings of crustal structure: one for the structure shown in Table 2 and other for water layer over half space.

of direct $\mathrm{P}$ wave and reflected phases, and synthesized and observed seismograms for SP1 event at COL station. The pulses represent rays before convolution with instrumental response, $\mathrm{Q}$ operator and source time function. The reflections 


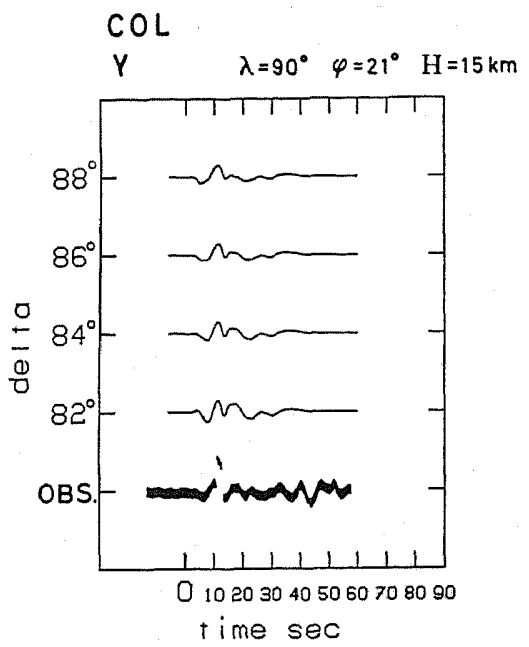

(a)

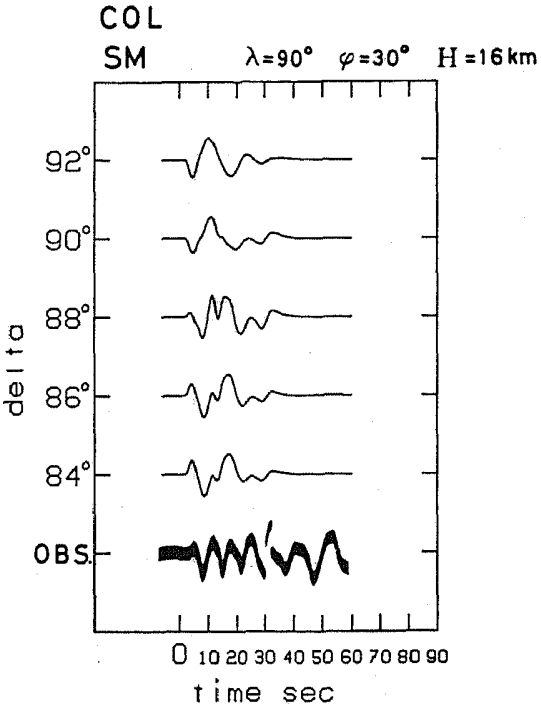

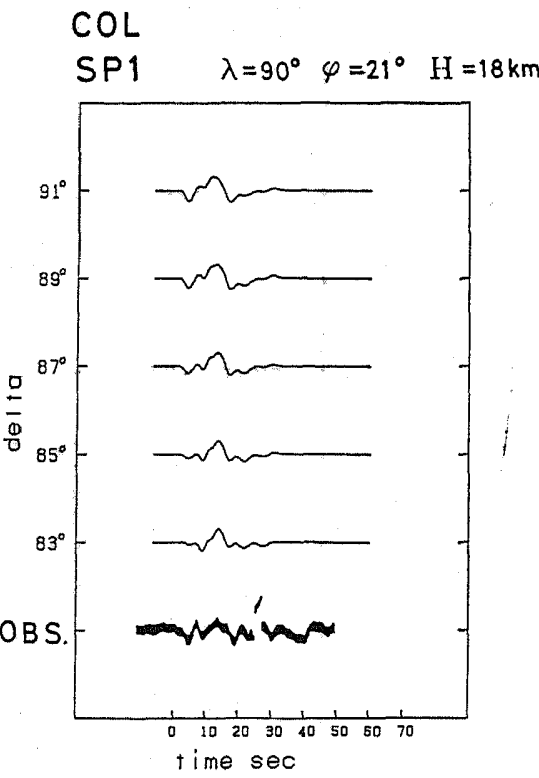

(c)

Fig. 5. (a), (b), and (c) Determination of dip angles, delta, of nearly vertical nodal planes at COL station for events Y, SM, and SP1, respectively. Synthetics for various dip angles are shown with observed seismograms. For events $Y, S M$, and $S P 1,84^{\circ}, 88^{\circ}$, and $87^{\circ}$ dip angles are obtained, respectively, from this comparison.

(b)

from the base of the sediment, indicated by pdP and sdP, are as large as the other depth phases pwP, $\mathrm{sP}$, and $\mathrm{pP}$. In the observed short-period seismogram we can clearly identify the pdP phase at the appropriate time before the largest pwP phase. At the bottom of this figure, we show the pulses and synthesized seismograms in which we modeled the near-source structure simply by a water layer over the half space. The synthesized short-period seismogram for this case, which lacks the pdP and sdP phases, does not fit the observed one. In the long- 
period records, identifying these depth phases is not as straightforward as for the short-period records. However, the difference in waveform between the synthetics for the two models is obvious; the one that includes the pdP and sdP phases matches the waveform better. We found in the course of this study that, in order to match the synthetics well with the observed seismograms, we had to vary the sediment thickness from station to station even for the same earthquake, although the range of this variation is small, as indicated in Table 2 . This is reasonable because the thickness of sediments seems to vary within a distance of about $10 \mathrm{~km}$ for some locations along the upper and lower trench slopes off the coast of northern Honshu (SCIENTIFIC PARTY, 1980).

\subsection{Mechanism determination}

In order to determine mechanisms for the studied events, we used the following procedure except for event SP2, which has a solution different from the others. First we constrained the strike of the nearly vertical nodal plane based on the P-wave first motions and S-wave polarization angles. Next, assuming pure dip-slip faulting, we determined the dip angle of this plane by matching the synthetics with the observed siesmograms using stations near the nodal line. In

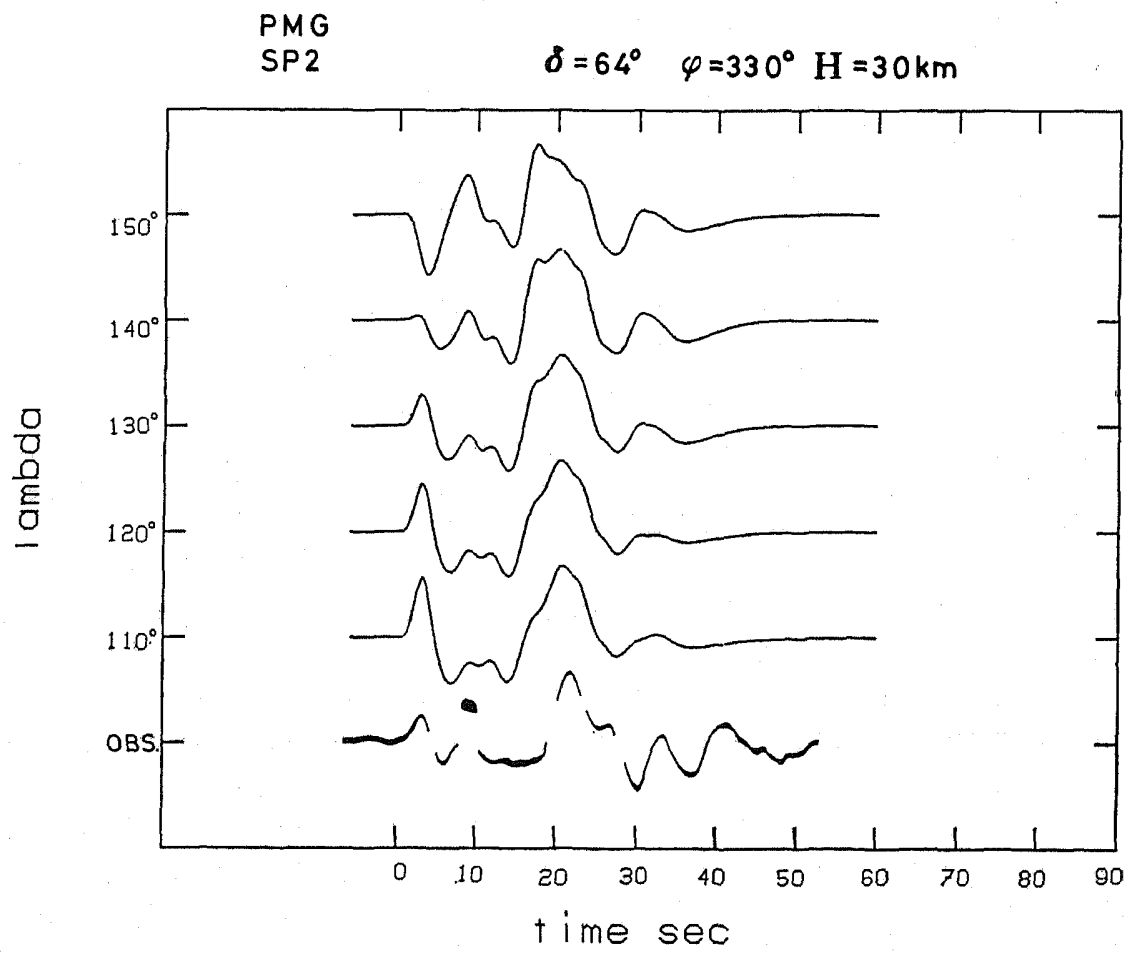

Fig. 6. Determination of slip angle at PMG station for event SP2. Synthetics for various slip angles, lambda, are shown with the observed seismogram. Slip angle of $130^{\circ}$ was obtained for this station. 


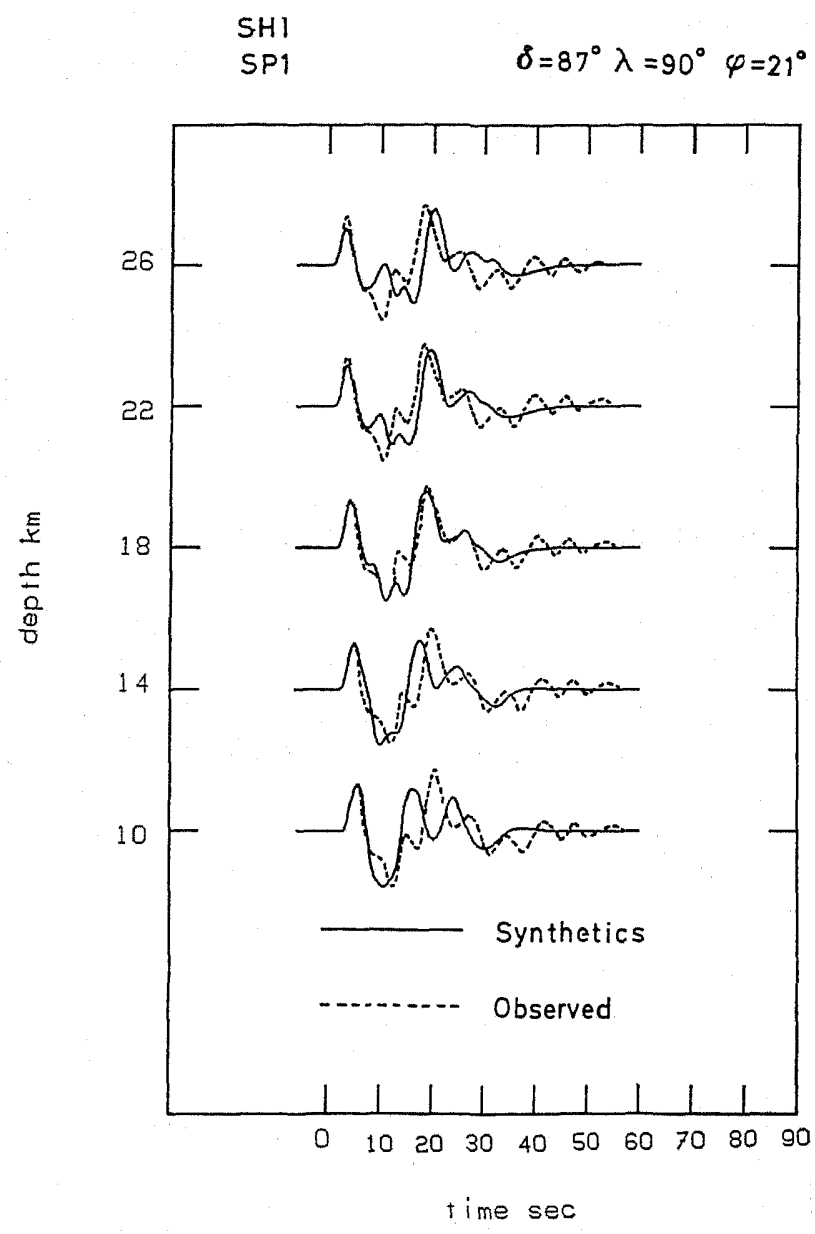

Fig. 7. Determination of source depth at SHI station for SP1 event. Synthetics for various depths are shown with the observed seismogram indicated by the dotted line. Depth determined for this station is $18 \mathrm{~km}$.

this step we obtained rough estimates of the source depth and source time function, and these were used to constrain the final mechanism. We had to assume pure dip-slip faulting because we could not constrain the shallower nodal plane through waveform comparisons. For events I1, I2, and SM, P-wave first motions are enough to obtain thrust type mechanism solutions, contrary to the previous mechanism solutions. However, for events $\mathrm{Y}$ and SP1, P-wave first motions alone could not discriminate between thrust type and normal fault type mechanisms (see Figs. 8); in this case synthetics were used effectively to discriminate mechanism type for these events. COL station was often the best station to constrain the dip angle, although we also used other stations near the nodal line. We show examples of dip angle determination for events $Y, S M$, and 


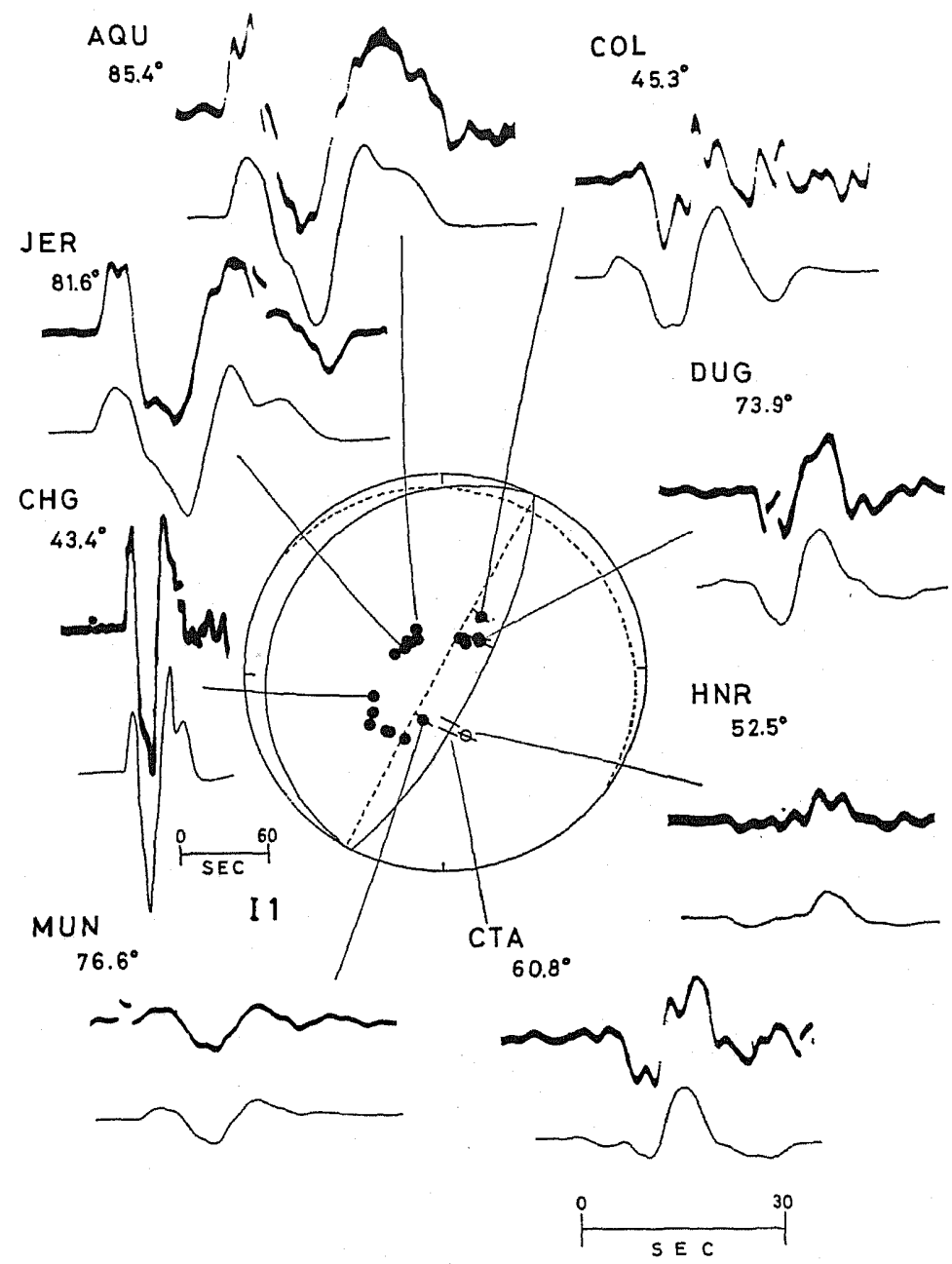

Fig. 8(a) (Caption at end)

SP1 at COL station in Figs. 5(a), (b), and (c). The dip angle larger than $90^{\circ}$ means normal faulting and less than $90^{\circ}$ thrust type in these figures.

For event SP2, which was previously found to have a strike-slip fault type mechanism, we constrained one nodal plane dipping to the northeast by using the P-wave first motions (see Fig. 8(f)). Assuming this fault plane, we determined a slip angle using PMG, BAG, and CTA stations. Determination of the slip angle at PMG station is shown in Fig. 6. Other stations gave the same results.

\subsection{Determination of source depth}

Source depth and source time functions were determined through matching the synthetics with the observed seismograms using the mechanism solution 


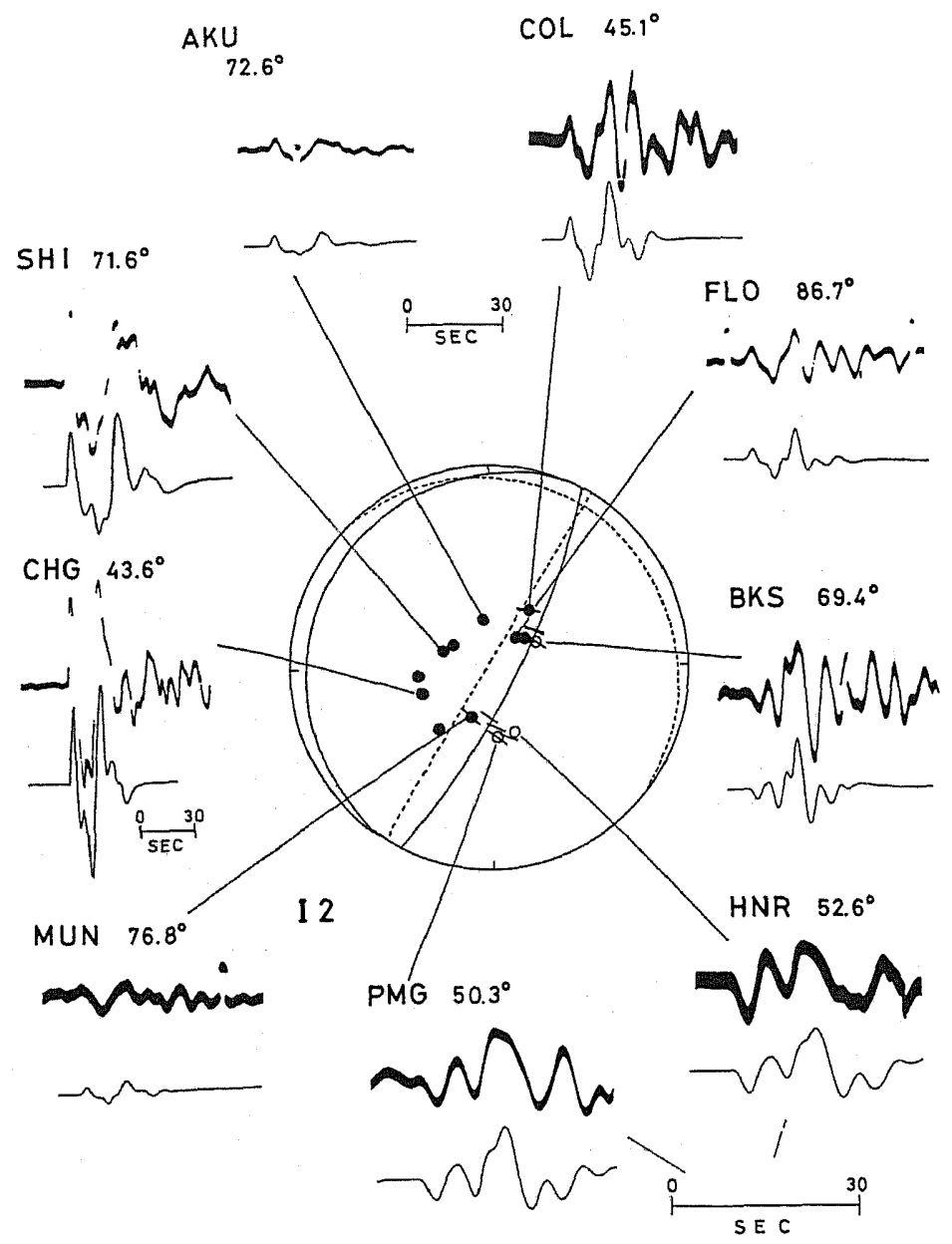

Fig. 8(b)

obtained as described in subsection 3.2. An example of the depth determination for event SP1 at SHI station is presented in Fig. 7. The formal error of the depth determination at each station is about $\pm 2 \mathrm{~km}$, provided that the crustal structure is correctly modeled. The stations used covered most azimuths except due east (see Figs. 8). The depths determined for various stations were averaged to obtain the final depth for each event. The standard deviation of depth determination is listed in Table 3 with the number of stations used. From six to twelve stations were used. The variation of depth among stations for each event was small except for event SP2.

Finiteness of the source was only included in the source time function; thus rupture propagation direction was neglected. The source time did not show any significant variation in azimuth for the five smaller events, and even for the largest 


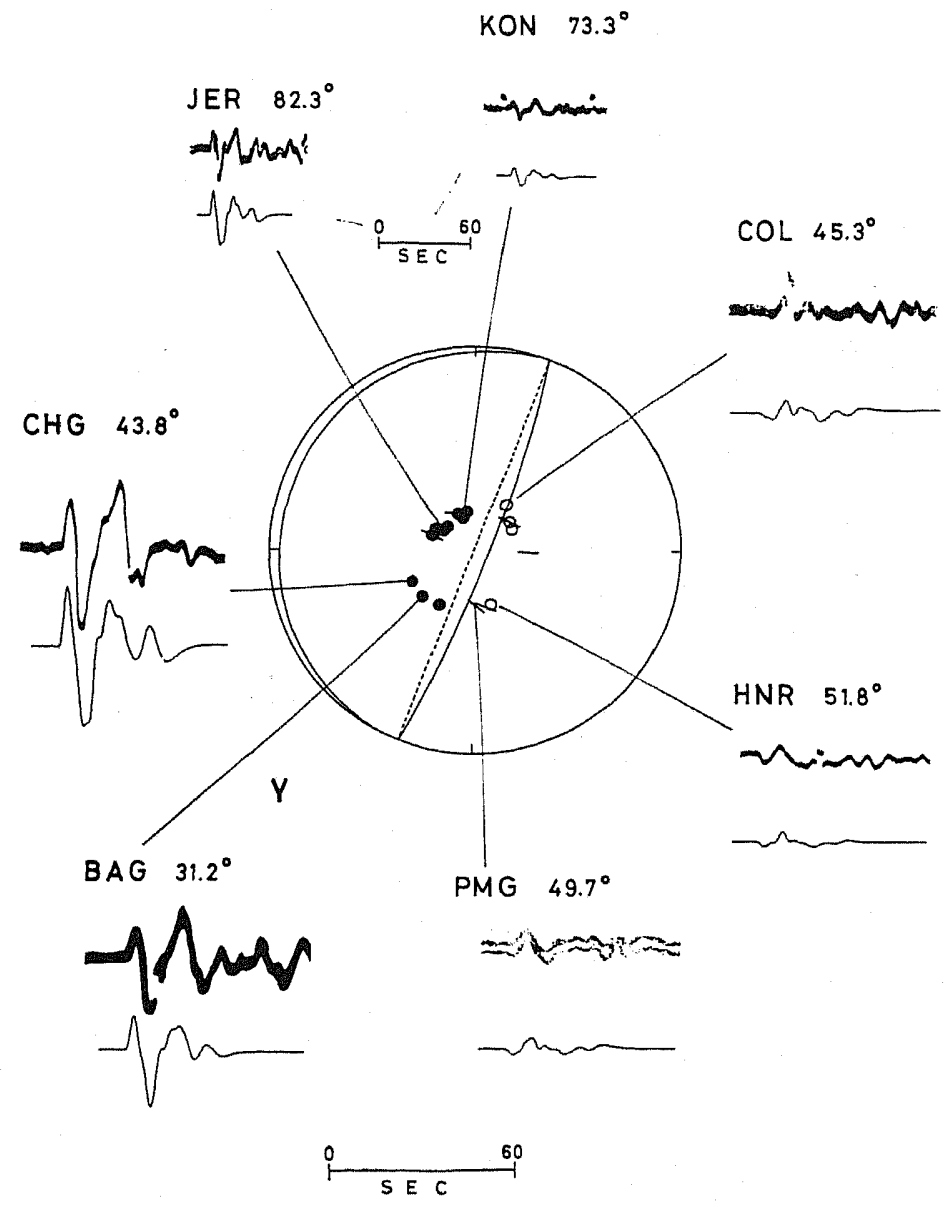

Fig. $8(\mathrm{c})$

Table 3. Source depths and fault plane solutions of the events studied.

\begin{tabular}{|c|c|c|c|c|c|c|c|c|}
\hline \multirow[b]{2}{*}{ Event } & \multirow[b]{2}{*}{ Date } & \multirow[b]{2}{*}{$\begin{array}{c}\text { Depth } \\
(\mathrm{km})\end{array}$} & \multirow[b]{2}{*}{$\begin{array}{l}\text { S.D. } \\
(\mathrm{km})\end{array}$} & \multirow{2}{*}{$\begin{array}{l}\text { Depth } \\
\text { ISC } \\
(\mathrm{km})\end{array}$} & \multirow{2}{*}{$\begin{array}{l}\text { Depth } \\
\text { pP-P } \\
(\mathrm{km})\end{array}$} & \multicolumn{3}{|c|}{ Fault parameters } \\
\hline & & & & & & $\begin{array}{l}\text { Strike } \\
\left(N^{\circ} E\right)\end{array}$ & $\operatorname{Dip}_{(0)}$ & $\begin{array}{c}\text { Rake } \\
\left({ }^{\circ}\right)\end{array}$ \\
\hline I1 & 65316 & 26 & $3.3(7)$ & 36 & 29 & 28 & 76 & 90 \\
\hline $\mathrm{I} 2$ & 68524 & 23 & $1.5(12)$ & 27 & 23 & 28 & 80 & 90 \\
\hline$Y$ & $68 \quad 622$ & 16 & $1.7(7)$ & 29 & 19 & 21 & 84 & 90 \\
\hline SM & 71915 & 16 & $2.0(8)$ & 30 & 20 & 30 & 88 & 90 \\
\hline SP1 & 68421 & 18 & $1.0(6)$ & 33 & 41 & 21 & 87 & 90 \\
\hline SP2 & 69316 & 33 & $5.5(7)$ & 33 & 37 & 330 & 64 & 130 \\
\hline
\end{tabular}

S.D. denotes standard deviation of depth determination; number in parentheses is the number of stations used. 


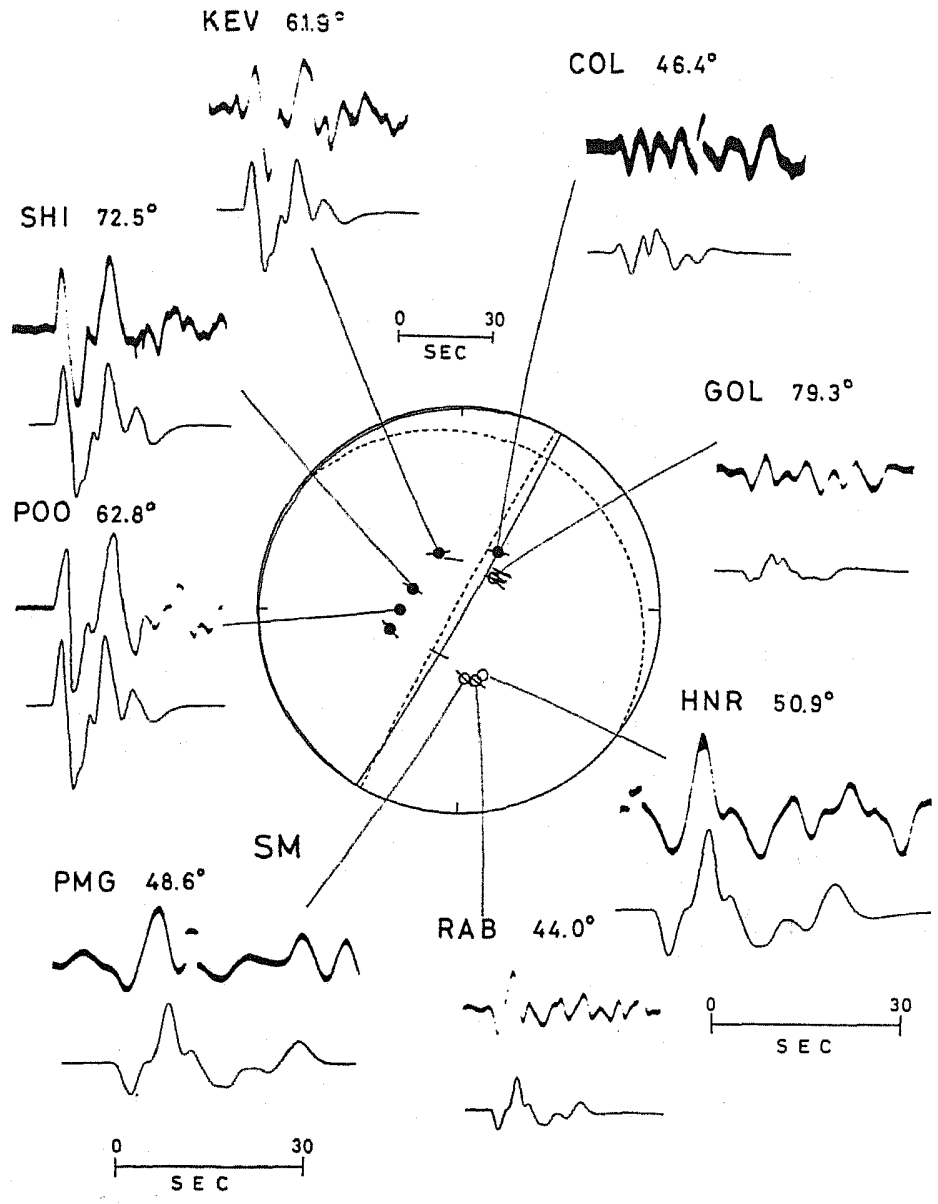

Fig. 8(d)

event (I1) it varied on the order of $1 \mathrm{sec}$. The trade-offs between the source duration and the later depth phases are not serious, except for event I1, because their source time is only $3 \mathrm{sec}$. The source time of event $I 1$ is around $7 \mathrm{sec}$ and even for this case the trade-off between the source time and the later depth phases is not too serious In any case, the depth determined in this study is a mean depth, in a sense, for the total rupture process. If rupture propagates vertically, the depth extent of rupture may be large. Note that typical rupture dimension of this size of events is $10 \mathrm{~km}$ (e.g., IzUTANI and Hirasawa, 1978). Fortunately, however, most events have thrust type mechanism (Figs. 8) and would thus have almost horizontal rupture propagation, which would reduce the uncertainty of depth determination. Event SP2 does not have a typical thrust type mechanism, and this event might have ruptured nearly vertically; this may have caused this event to have a larger error in depth determination than the other events (Table 3). 


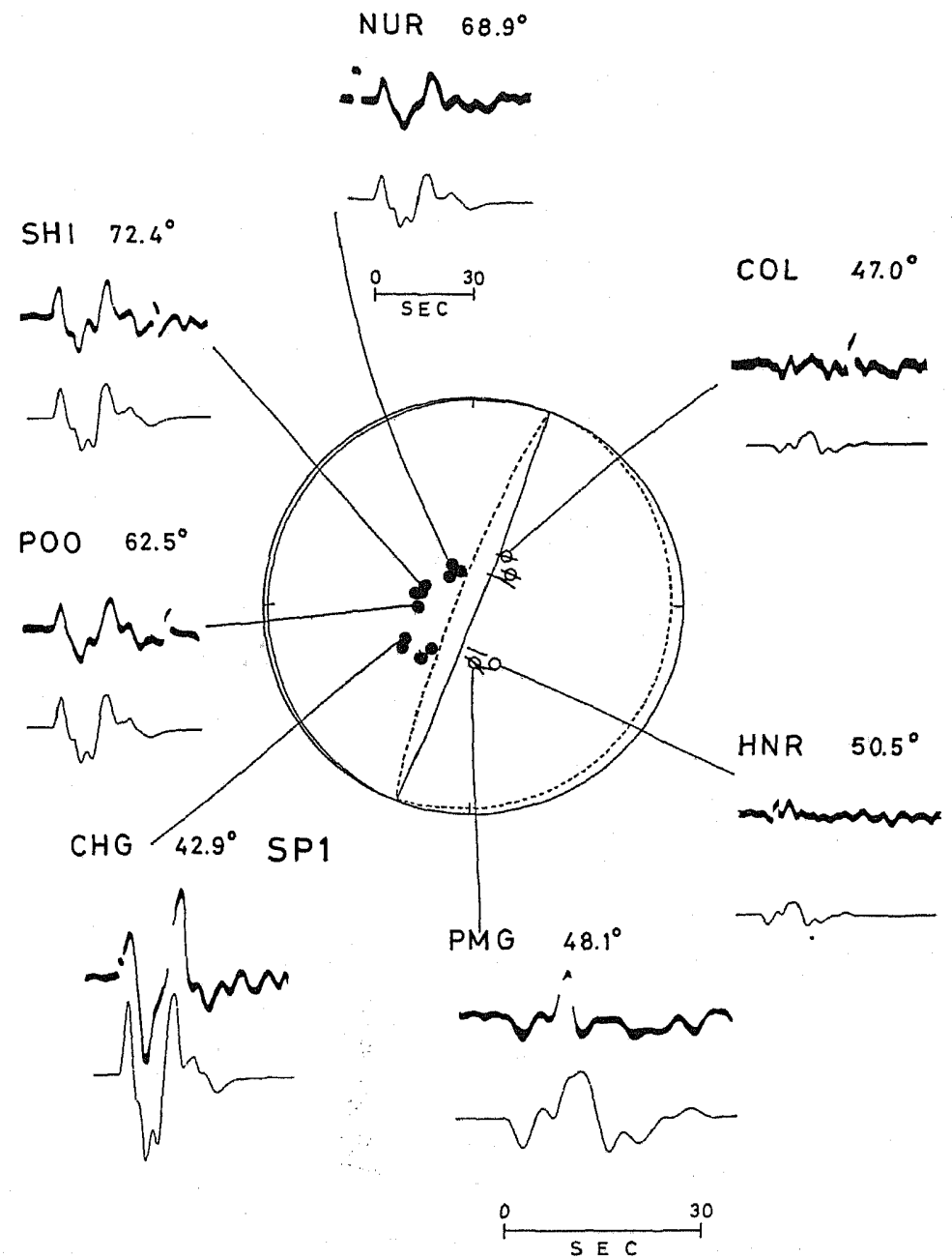

Fig. 8(e)

\section{Results}

The parameters of fault plane solutions and source depths determined in this study are listed in Table 3. The comparisons between the synthetics and observed seismograms are shown in Figs. 8, with the equal area projection of $\mathbf{P}$-wave first motions and nodal lines at the center of each figure. The dotted lines indicate the solutions from previous authors and the solid lines the solutions in this study.

Out of six earthquakes in Table 1, five events were found to be of thrust type, contrary to the previously published mechanisms. The sixth event (March $16,1969, m_{\mathrm{b}}=5.5, M_{\mathrm{S}}=5.5$ ), which is located about $100 \mathrm{~km}$ landward of the trench 

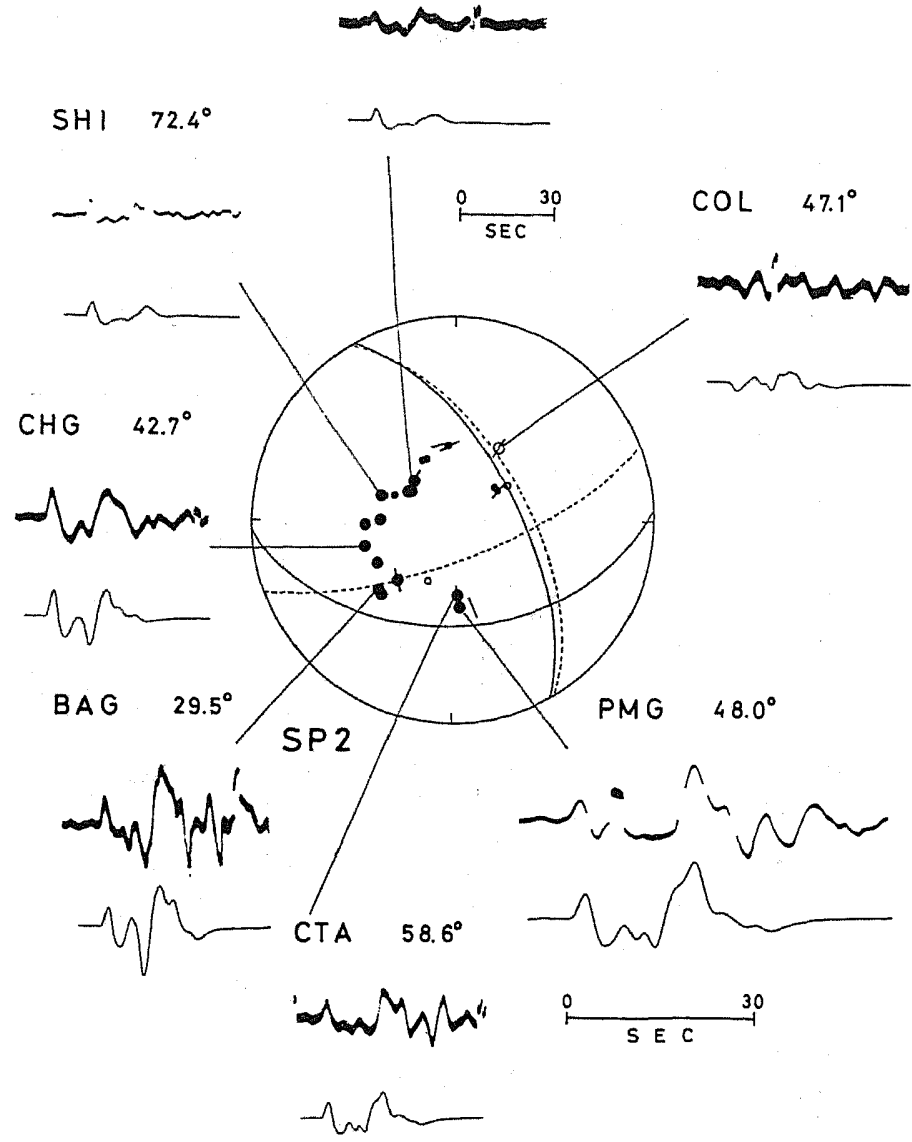

Fig. 8(f)

Fig. 8. (a), (b), (c) (d), (e), and (f) Comparison in waveform between the synthesized and observed seismograms for the fault parameters obtained in this study. At the center of each figure, focal mechanism diagram is shown with $\mathrm{P}$-wave first motions and $\mathrm{S}$-wave poralization angles in an equal area projection of the lower hemisphere. Nodal lines are indicated by the solid line and the dotted line for the parameters obtained in this study and in the previous studies, respectively. Numbers attached at each station code is the epicentral distance in degree. Trapezoidal source time function $\left(T_{0}, T_{1}, T_{2}\right)$ is $(1.0,1.0,1.0 \mathrm{sec})$ except for event II. Event Il has $(1.0,5.0$, $1.0 \mathrm{sec}$ ) source time.

axis, has a mechanism definitely different from the other thrust type earthquakes. It has one nodal plane dipping shallow to the south and another dipping steeply to the northeast.

In Table 3, we also list the depths reported in the ISC Bulletins: the depth determined routinely and the depth determined from $\mathrm{pP}$ phases and corrected 

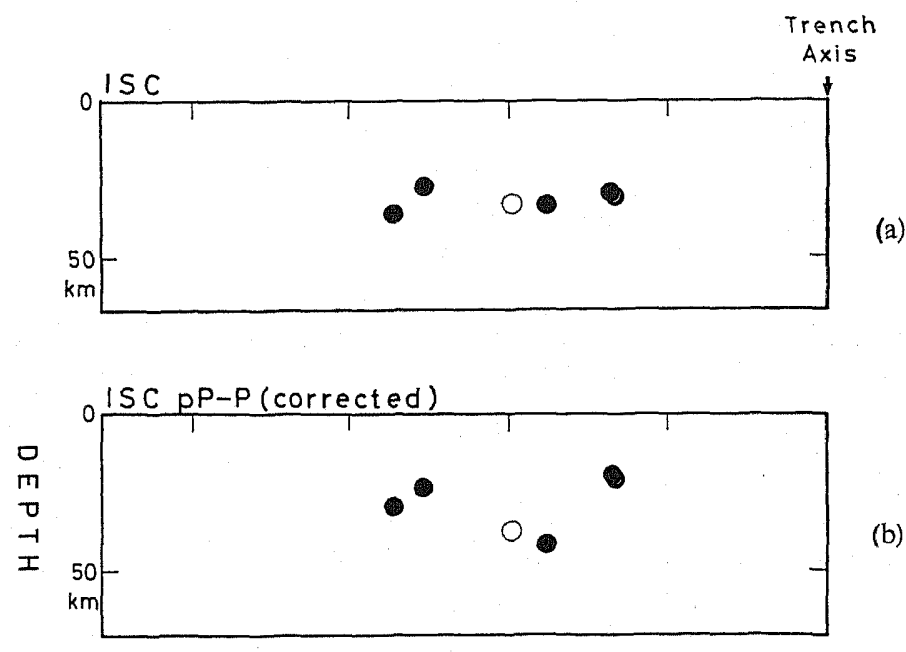

(a)

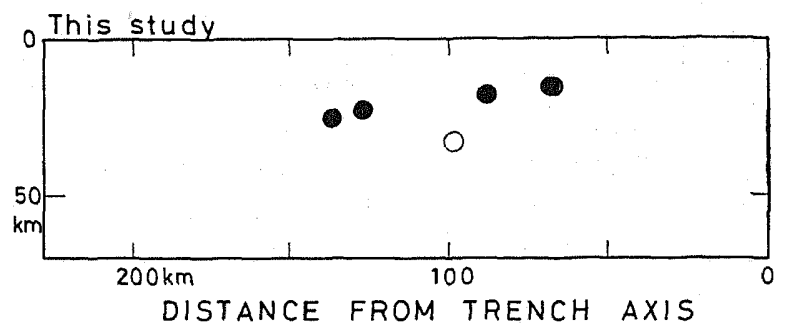

(b)

(c)

Fig. 9. (a), (b), and (c) Foci of the six events in a cross-section perpendicular to the trench axis. (a) ISC routine depth, (b) ISC pP-P depth corrected, (c) depth obtained in this study. The focus of event SP2 is indicated by the open circle, which is located deeper than the lineup of other thrust type events in (c).

for the water depth (YosHII, 1979a, b). The foci, based on ISC, ISC depth phase corrected, and this study, are shown in a cross-section perpendicular to the trench axis in Figs. 9(a), (b), and (c), respectively. In this figure, SP2 event is indicated by the open circle and other events by the solid circles. The depths determined in this study coincide within $4 \mathrm{~km}$ with the depths from $\mathrm{pP}$ phase corrected except for one event (SP1), but differ greatly from those of the ISC routine determinations. In Fig. 9(c), the foci of the five thrust type events line up dipping slightly to the landward and event SP2 is located $15( \pm 5) \mathrm{km}$ deeper than the nearby thrust type event, SP1.

\section{Discussion and Conclusions}

The solutions previously obtained were revised significantly in this study. We should briefly discuss here why the previous authors have given solutions different from the present results. The solutions by ICHIKAWA (1971) for I1 and 
I2 events are based on the short-period P-wave first motions reported in various bulletins. Thus the apparent inconsistency between his solutions and long-period P-wave first motions in Figs. 8(a) and (b) would have resulted from the incorrect short-period data. In the course of this study, we found that IzUTANI and HirASAWA (1978) studied event II using long-period P and S waves. They took into account the $\mathrm{pP}$ and $\mathrm{sP}$ phases and the finiteness of rupture. Their mechanism solution (strike $\mathrm{N} 18^{\circ} \mathrm{E}$, dip $72.5^{\circ}$, rake $85^{\circ}$ ) and source depth $(26 \mathrm{~km})$ are almost identical to those of the present study except for the fault strike. For events SM and SP2, there was an obvious misidentification or omission of long-period Pwave first motions in their previous solutions. For events $Y$ and SP1, it is impossible to determine the precise dip of their nearly vertical nodal planes from the long-period P-wave first motions alone. YoshII (1979a)'s solution is one possible solution if only P-wave first motions are used. SENo and Pongsawat (1981) determined a normal fault type mechanism for SP1 event using supplementarily $\mathrm{P}$-wave first motions recorded at regional stations in northern Honshu. The ISC pP corrected depth which they used is $41 \mathrm{~km}$, significantly greater than the depth obtained in this study. This greater depth resulted in incorrect take-off angles for nearby stations in northern Honshu and consequently in their normal fault type mechanism. We have demonstrated in this study that bodywave synthetics can be effectively used to determine precise focal mechanisms when $\mathrm{P}$-wave first motions or S-wave poralization angles alone cannot determine nodal planes. Comparing body-wave synthetics with the observed waveforms also aids in the identification of first-motion polarities for stations near the nodal planes.

The five events which were previously believed to be of normal fault type were found to be as low-angle thrust events. Thus faulting within the slab between the trench axis and the double seismic zone in the northern Honshu arc does not seem as prevalent as suggested by previous work (SASATANI, 1971; YoshII, 1979a). SASATANI (1971) used the spatial distribution of P-wave first motion polarities recorded at Japanese stations to investigate the mechanisms of earthquakes offshore of northern Honshu. However, the take-off angles he used are very sensitive to the focal depth used, and the focal depths of the offshore events in his study do not seem well-determined. A small change of the focal depth near the Moho discontinuity will change his identification of the fault type. Thus his identification of the mechanism type deserves reexamination using more accurate focal depths. YosHII (1979a) drew a schematic figure for the mechanism type distribution in the cross-section normal to the northern Honshu arc. $\mathrm{He}$ described normal fault type events predominating within the slab about $100 \mathrm{~km}$ landward from the trench axis. However, this was based on his solution for event $\mathrm{Y}$ and solutions by ICHIKAWA (1971) including events I1 and I2, which have been revised to thrust type solutions in this study. Therefore, we believe that his proposal of normal faulting within the slab landward of the trench axis is not supported by any seismological evidence at present. Our study does not show that 
normal faulting is the predominant mode of deformation in the shallower portion of the slab landward of the trench in the northern Honshu arc. However, because the time period treated in this study is only the last fifteen years and there remain several major events in this arc whose mechanisms have not been analyzed, we have to await future studies before concluding that normal faulting is not significant within the slab landward of the trench axis and seaward of the double seismic zone in this region.

Figure 10 shows the six events we studied plotted in a cross-section perpendicular to the arc along with other earthquakes for which mechanism types were analyzed by KawaKatsu and Seno (1983) and Seno and Pongsawat (1981). The down-dip compression and tension type events are indicated by symbols $\mathrm{C}$ and $T$, respectively, and the low-angle thrust type by $\mathrm{D}$. The shallower nodal planes for the five thrust type events and $\mathrm{T}$ axis for SP2 event are also projected in this cross-section. The nodal planes of the five thrust type events are more or less tangential to the lineup of the foci of these events, although the dip and strike of these shallower nodal planes are not well constrained. Their strike has an uncertainty of a few tens of degrees. However, we believe that those shallower nodal planes are the fault planes because the lineup of these events is remarkable and probably defines the plate interface in the region. IZUTANI and HIRASAWA

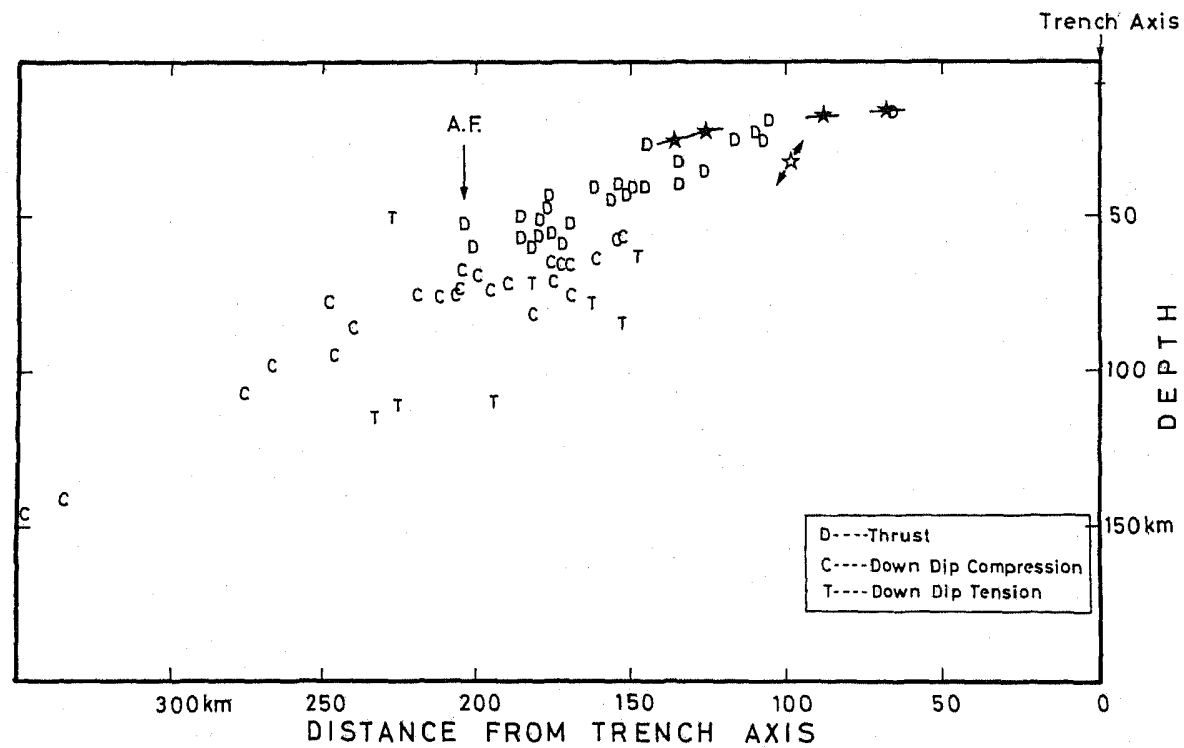

Fig. 10. Cross-section of fault types of earthquakes perpendicular to the trench axis. Down-dip compression (C), down-dip tension (T), and thrust (D) type events are from KaWAKaTSU and SENo (1983); only events north of $38^{\circ} \mathrm{N}$ are plotted. The asterisks indicate the studied events. The shallower nodal planes for events I1, I2, $\mathrm{SM}, \mathrm{Y}$, and $\mathrm{SP1}$ and the $\mathrm{T}$ axis for event $\mathrm{SP} 2$ are also projected. A.F. denoted the aseismic front (YosHrr, 1979b). 
(1978) studied event I1 and five other thrust type events which occurred off the northeastern coast of northern Honshu and showed that the shallower nodal planes are the fault planes, using aftershock locations and rupture propagation direction. The slip vectors of the thrust type events in this study range from $\mathrm{N} 60^{\circ} \mathrm{W}$ to $\mathrm{N} 69^{\circ} \mathrm{W}$ and are consistent with the slip vectors of major thrust type events along the northern Honshu arc (e.g., Seno and EGUCHI, 1983; IzUTANI and HrRasawa, 1978).

The sixth event (SP2) definitely occurred within the slab $15( \pm 5) \mathrm{km}$ below the plate interface. The double seismic zone appears $150 \mathrm{~km}$ landward of the trench axis. The location of event SP2 is thus separated by $50 \mathrm{~km}$ from the double seismic zone; this suggests that the stress causing this event is not directly related to the stresses which create the double seismic zone. Apparently the stress orientation of this event cannot be explained by bending or unbending of the elastic-plastic plate (ENGDAHL and SHOLZ, 1977; ISACKS and BARAZANGI, 1977; CHAPPLE and ForSYTH, 1979) because the stress axes are not parallel to the dip of the slab. This event provides evidence that stresses other than those creating the double seismic zone are acting within the more seaward portion of the slab. Gravitational pull (KANAMORI, 1971b) or sagging (SLEEP, 1979) of the downgoing slab is a possible cause for the event. The stress pattern calculated by SLEEP (1979) is consistent with the orientation of the $T$ axis of this event, although the direct comparison does not hold because his model is for the shorter Aleutian slab. Lateral compression, which usually appears within the slab near the junction of the arcs (e.g., ISACKs and Molnar, 1971; SASATANI, 1976), is another possibile cause of the event, because the $\mathrm{P}$ axis of the event is subparallel to the arc strike. However, the location of this event is far from the arc junction and there is no seismological indication which suggests that lateral bending is dominant within the slab beneath the northern Honshu arc.

Studies which include precise determination of the mechanism and the location of events with respect to the descending slab will provide constraints for the mechanical and rheological behavior of the slab near the deep-sea trench, where the slab has to deform extensively. In this study we have sought to obtain this kind of information just landward of the trench. Yet much more about the precise geometry and stress states of the slab has to be known before detailed discussion of the mechanical and rheological behavior of the slab after it descends beneath the trench is possible.

We express our thanks to Bob Geller who encouraged us throughout this study. We also wish to thank Hitoshi Kawakatsu and Joe Stefani for helpful discussions and the use of their computer programs and T. Yoshii for providing us a tape of File ME1. This work was supported under NSF Grant EAR 80-19463, EAR 81-08718, and EAR 83-06555.

\section{REFERENCES}

ABE, K., Mechanisms and tectonic implications of the 1966 and 1970 Peru earthquakes, Phys. Earth Planet. Inter., 5, 367-379, 1972. 
ABE, K., Tectonic implications of the large Shioya-Oki earthquakes of 1938, Tectonophysics, 41, 269-289, 1977.

Asano, S., T. Yamada, K. Suyehiro, T. Yoshir, Y. Misawa, and S. Irzuka, Crustal structure in a profile off the Pacific coast of northeastern Japan by refraction method using ocean bottom seismometers, J. Phys. Earth, 29, 267-282, 1981.

Chapple, W. M. and D. W. Forsyth, Earthquakes and bending of plates at trenches, J. Geophys. Res., 84, 6729-6749, 1979.

Chase, T. E. and H. W. Menard, Bathymetric Atlas of the Northwestern Pacific Ocean, U. S. Naval Oceanographic Office, Washington, D.C., 1969.

Chung, W. Y. and H. KANAMORI, Subduction process of a fracture zone and aseismic ridgesThe focal mechanism and source characteristics of the New Hebrides earthquake of 1969 January 19 and some related events, Geophys. J. R. Astron. Soc., 54, 221-240, 1978.

EnGDAHL, E. R. and C. H. SHolz, A double Benioff zone beneath the central Aleutians and unbending of the lithosphere, Geophys. Res. Lett., 4, 473-476, 1977.

Helmberger, D. V., Generalized ray theory for shear dislocation, Bull. Seismol. Soc. Am., 64, 45-64, 1974.

HousE, L. S. and K. H. JACOB, Earthquakes, plate subduction and stress reversals in the eastern Aleutian arc, J. Geophys. Res., 88, 9347-9373, 1983.

ICHIKAWA, M., Reanalysis of mechanism of earthquakes which occurred in and near Japan, and statistical studies on the nodal plane solutions obtained, 1926-1968, Geophys. Mag., 35, 207-273, 1971.

ISACKS, B. L. and M. BARAZANGI, Geometry of Benioff zones: Lateral segmentation and downward bending of the subducted lithosphere, in Island Arcs Deep Sea Trenches and Back Arc Basins, Maurice Ewing Series, I, ed. M. Talwani and W. C. Pitman III, pp. 99-114, AGU, Washington, D.C., 1977.

ISACKS, B. L. and P. MolNAR, Distribution of stresses in the descending lithosphere from a global survey of focal-mechanism solutions of mantle earthquakes, Rev. Geophys. Space Phys., 9, 103-174, 1971.

IzUTANI, Y. and T. HrRASAWA, Source characteristics of shallow earthquakes in the northern part of Sanriku-Oki region, Japan, J. Phys. Earth, 26, 275-298, 1978.

KANAMORI, H., Seismological evidence for a lithospheric normal faulting: the Sanriku earthquake of 1933, Phys. Earth Planet. Inter, 4, 289-300, 1971 a.

Kanamori, H., Great earthquakes at island arcs and the lithosphere, Tectonophysics, 12, 187$198,1971 \mathrm{~b}$.

Kanamorr, H. and G.S. Stewart, Mode of the strain release along the Gibbs fracture zone, mid-Atlantic ridge, Phys. Earth Planet. Inter., 11, 312-332, 1976.

Kawakatsu, H. and T. SENO, Triple seismic zone and the regional variation of seismicity along the northern Honshu arc, J. Geophys. Res., 88, 4215-4230, 1983.

Kroeger, G. C. and R. J. Geller, An efficient method for synthesizing teleseismic body waves for shallow sources in a vertically stratified medium, J. Geophys. Res., 1983 (in press).

Langston, C. A. and D. V. Helmberger, A procedure for modeling shallow dislocation sources, Geophys. J. R. Astron. Soc., 42, 117-130, 1975.

Malgrange, M. A., A. Deschamps, and R. Madariaga, Thrust and extensional faulting under the Chilian coast: 1965, 1971 Aconcagua earthquakes, Geophys. J. R. Astron. Soc., 66, 313-332, 1981.

Malgrange, M. A. and R. Madariaga, Complex distribution of large thrust and normal fault earthquakes in the Chilean subduction zone, Geophys. J. R. Astron. Soc., 73, 489-505, 1983.

ReYners, M. and K.S. Coles, Fine structure of the dipping seismic zone and subduction mechanics in the Shumagin islands, Alaska, J. Geophys. Res., 87, 356-366, 1982.

Sasatani, T., Distribution of the P-wave initial motions by earthquakes occurred on the Pacific coast side in the northeast Japan, Geophys. Bull. Hokkaido Univ., 25, 243-258, 1971 (in 
Japanese).

SASATANI, T., Mechanism of mantle earthquakes near the junction of the Kurile and the northern Honshu arc, J. Phys. Earth, 24, 341-354, 1976.

ScIENTIFIC PARTY, Initial Reports of the Deep Sea Drilling Project, 56, 57, U.S. Govt. Printing Office, Washington, D.C., 1980.

SENO, T., Seismicity and earthquake mechanisms prior to the Miyagi-Oki, Japan, earthquake of June 12, 1978, preprint, 1982.

Seno, T. and T. EguCHI, Seismotectonics of the western Pacific region, in Geodynamics of the Western Pacific-Indonesian Region, Geodynamics Series 11, ed. T. W. C. Hilde and S. Uyeda, pp. 5-40, AGU/GSA, Washington, D.C., 1983.

Seno, T. and B. Pongsawat, A triple-planed structure of seismicity and earthquake mechanisms off Miyagi Prefecture, northern Honshu, Japan, Earth Planet. Sci. Lett., 55, 25-36, 1981.

Shimamura, H., Distribution of thickness of the Kurile plate and hypocentral distribution of earthquakes within the plate, Abstr. Seismol. Soc. Japan, 1, 118, 1973.

SLEEP, N. H., The double seismic zone in downgoing slabs and the viscosity of the mesosphere, J. Geophys. Res., 84, 4565-4571, 1979.

STAUDER, W., Mechanism and spatial distribution of Chilean earthquakes with relation to subduction of the oceanic plate, J. Geophys. Res., 78, 5033-5061, 1973.

Stauder, W., Subduction of the Nasca plate under Peru as evidenced by focal mechanisms and by seismicity, J. Geophys. Res., 80, 1053-1064, 1975.

STAUDER, W. and L. MUALCHIN, Fault motion of the larger earthquakes of the Kurile-Kamchatka arc and of the Kurile-Hokkaido corner, J. Geophys. Res., 81, 297-308, 1976.

Stern, S. J., F. Engeln, D. A. Wiens, K. Fujta, and R. C. Speed, Subduction seismicity and tectonics in the Lesser Antilles arc, J. Geophys. Res., 87, 8642-8664, 1982.

YosHII, T., A detailed cross-section of the deep seismic zone beneath Japan, Tectonophysics, 55, 349-360, 1979a.

YosHII, T., Compilation of geophysical data around the Japanese islands, Bull. Earthq. Res. Inst., Univ. Tokyo, 54, 75-117, $1979 \mathrm{~b}$ (in Japanese). 